\title{
DÜBLIN
}

Technological University Dublin

ARROW@TU Dublin

\section{In-Package Atmospheric Pressure Cold Plasma Treatment of Strawberries}

\author{
N. Misra \\ Technological University Dublin, misra.nrusimhanath@tudublin.ie \\ Paula Bourke \\ Technological University Dublin, paula.bourke@tudublin.ie \\ Patrick Cullen \\ Technological University Dublin, pj.cullen@tudublin.ie
}

See next page for additional authors

Follow this and additional works at: https://arrow.tudublin.ie/schfsehart

Part of the Food Processing Commons, and the Plasma and Beam Physics Commons

\section{Recommended Citation}

Misra, NN, Patil, S, Moiseev, T, Bourke, P, Mosnier, JP, Keener, KM, \& Cullen, PJ (2013) In-package atmospheric pressure cold plasma treatment of strawberries, Journal of Food Engineering, DOI:10.1016/ j.jfoodeng.2013.10.023.

This Article is brought to you for free and open access by the School of Food Science and Environmental Health at ARROW@TU Dublin. It has been accepted for inclusion in Articles by an authorized administrator of ARROW@TU Dublin. For more information, please contact arrow.admin@tudublin.ie, aisling.coyne@tudublin.ie, gerard.connolly@tudublin.ie.

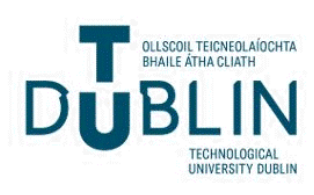


Authors

N. Misra, Paula Bourke, Patrick Cullen, and Sonal Patil

This article is available at ARROW@TU Dublin: https://arrow.tudublin.ie/schfsehart/115 


\section{Accepted Manuscript}

In-package atmospheric pressure cold plasma treatment of strawberries

N.N. Misra, Sonal Patil, Tamara Moiseev, Paula Bourke, J.P. Mosnier, K.M.

Keener, P.J. Cullen

PII:

S0260-8774(13)00538-4

DOI:

http://dx.doi.org/10.1016/j.jfoodeng.2013.10.023

Reference:

JFOE 7603

To appear in:

$$
\text { Journal of Food Engineering }
$$

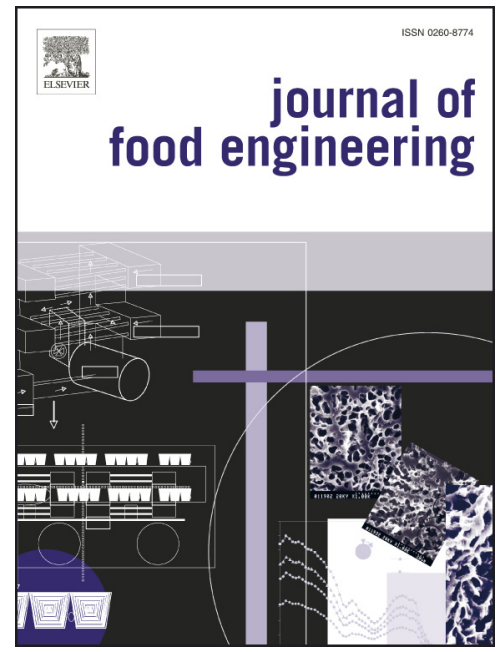

Received Date: 19 March 2013

Revised Date: $\quad 12$ August 2013

Accepted Date: 17 October 2013

Please cite this article as: Misra, N.N., Patil, S., Moiseev, T., Bourke, P., Mosnier, J.P., Keener, K.M., Cullen, P.J., In-package atmospheric pressure cold plasma treatment of strawberries, Journal of Food Engineering (2013), doi: http://dx.doi.org/10.1016/j.jfoodeng.2013.10.023

This is a PDF file of an unedited manuscript that has been accepted for publication. As a service to our customers we are providing this early version of the manuscript. The manuscript will undergo copyediting, typesetting, and review of the resulting proof before it is published in its final form. Please note that during the production process errors may be discovered which could affect the content, and all legal disclaimers that apply to the journal pertain. 


\section{In-package atmospheric pressure cold plasma treatment of strawberries}

N. N. Misra ${ }^{1}$, Sonal Patil ${ }^{1}$, Tamara Moiseev ${ }^{2}$, Paula Bourke ${ }^{1}$, J. P. Mosnier ${ }^{2}$, K.M. Keener ${ }^{1,3}$, P. J. Cullen ${ }^{1}$

${ }^{1}$ School of Food Science and Environmental Health, Dublin Institute of Technology, Cathal Brugha Street, Dublin 1, Ireland

${ }^{2}$ School of Physical Sciences and National Centre for Plasma Science and Technology, Dublin City University, Glasnevin, Dublin 9, Ireland

${ }^{3}$ Department of Food Science, Purdue Agriculture, Purdue University, 745 Agriculture Mall Drive, West Lafayette, IN 47907, USA

Corresponding author: P. J. Cullen; pjcullen@dit.ie ( $ه$ ) Tel: +353 14027595 (留) 


\section{Abstract}

The ability to generate low temperature plasma at atmospheric pressure offers new opportunities to decontaminate biological materials, including fresh foods. In this study, strawberries were treated with atmospheric cold plasma (ACP), generated with a $60 \mathrm{kV}$ dielectric barrier discharge (DBD) pulsed at $50 \mathrm{~Hz}$, across a $40 \mathrm{~mm}$ electrode gap, generated inside a sealed package containing ambient air ( $42 \%$ relative humidity). The current-voltage characteristics revealed that the plasma operated in the filamentary regime. The background microflora (aerobic mesophillic bacteria, yeast and mould) of strawberries treated for $5 \mathrm{~min}$ was reduced by $2 \log _{10}$ within $24 \mathrm{~h}$ of post-ACP treatment. The respiration rate of ACP treated produce, measured by the closed system approach, showed no significant increase. The effect of ACP on strawberry colour and firmness was insignificant.

\section{Keywords}

Cold Plasma, Strawberries, Decontamination, Respiration rate, Quality, Nonthermal 


\section{Contents}

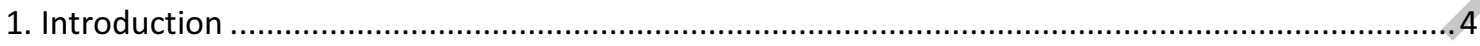

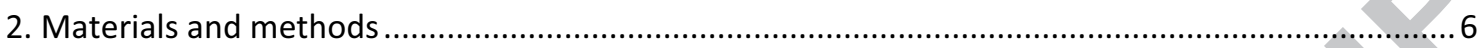

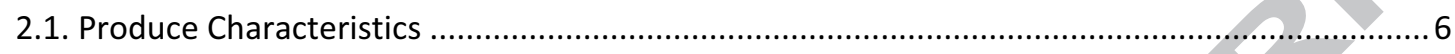

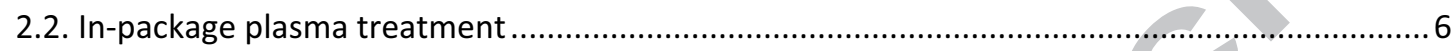

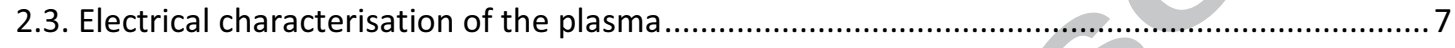

2.4. Measurement of ozone concentration ........................................................................... 8

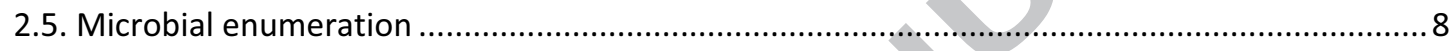

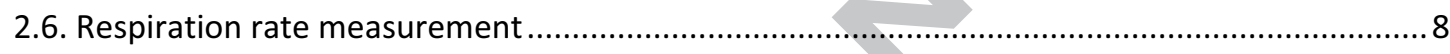

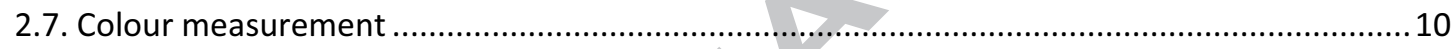

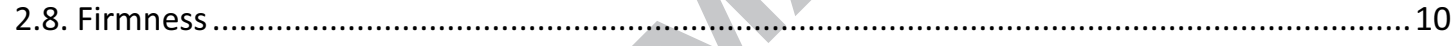

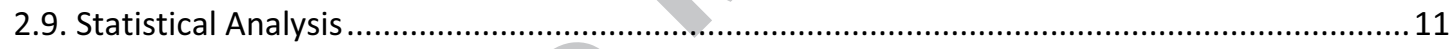

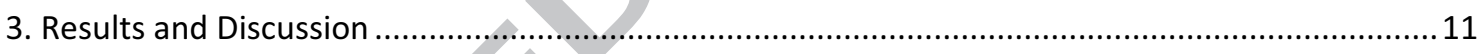

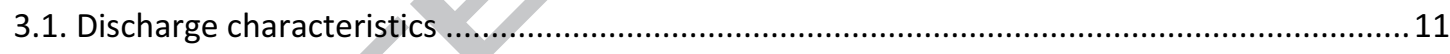

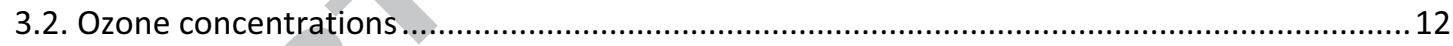

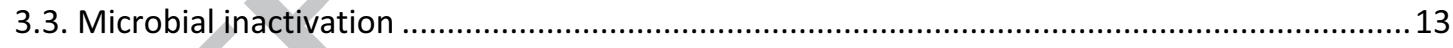

3.4. Respiration rate of cold plasma treated strawberries ............................................................ 14

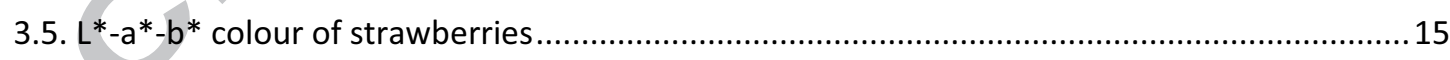

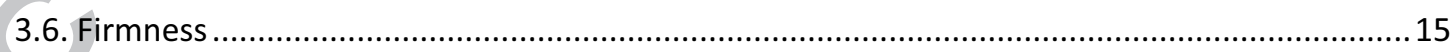

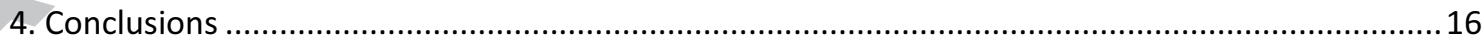

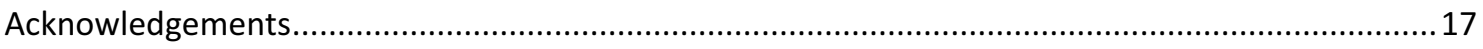

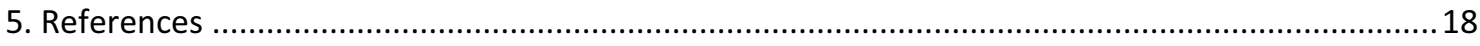




\section{Introduction}

Strawberries are known for their flavour and nutritional value. Strawberries are rich in bioactive compounds such as phenolic compounds, including their abundant anthocyanins, which impart the bright red colour to the fruits. Freshly harvested strawberries are very susceptible to mechanical injury, dehydration, decay and physiological deterioration. For this reason, strawberries are harvested and packed in the field directly into retail clamshell containers that are delivered to the supermarket. However, post-harvest spoilage of strawberry can be mainly attributed to the high incidence of yeast and mould growth (Garcia et al., 2011; Narciso et al., 2007).

Chlorine-based washing for decontamination is widely used by fresh produce processors. However, in some European countries including Germany, The Netherlands, Switzerland and Belgium the use of chlorine for washing fresh and fresh-cut products is prohibited (EU Directive 2092/91; Nguyen-the and Carlin, 1994). In addition, to address issues of chemical contamination, most processors seek to minimize or avoid the use of conventional preservatives and chemical antimicrobials (Misra et al., 2011a). Consumer demands and the shortcomings of the existing technologies are thus stimulating the development of alternative and preferably non-thermal approaches to processing of fresh produce (Deliza at al., 2003; Jeyamkondan et al., 1999). Food industries are seeking suitable technologies to ensure optimum microbiological safety and quality of minimally processed foods (Castenmiller et al., 2008; Misra et al., 2011a).

Nonthermal technologies such as high pressure processing (HPP) and pulsed electric field (PEF) technologies have already commercialised and provide good results (Suzuki, 2002). However, the equipment and set-up for HPP is capital intensive (Hugas et al., 2002), while PEF is only suitable for liquid foods. Nonthermal approaches for achieving decontamination of fresh whole fruits and vegetables include pulsed light processing (Gómez-López et al., 2007), ionising radiation, ultrasound 
or ozone assisted washing (Bilek and Turantas, 2002; Pangloli and Hung, 2013) and use of other chemical or packaging approaches (Ramos et al., 2013). Challenges of adoption of such technologies include; the shadowing effect in UV light processing, consumer acceptance and facility set-up for ionising radiation and the lack of suitable industrial scale processing units for ultrasound processing (Deora et al., 2013). Washing methods combined with chemical approaches have provided some success; nevertheless, this demands large volumes of water at industrial scale. Considering these aspects, research to develop suitable food processing technologies aiming to overcome such limitations is desirable and timely.

In this context, atmospheric pressure cold plasma (ACP) offers distinct advantages for decontamination of foods. The term "plasma" refers to an overall electrically neutral gas composed of molecules, atoms, ions and free electrons. In ACP, the electron temperature is much larger than the ion and neutral temperatures which are typically equal and close to room temperature ("cold" or non-thermal). The ACP gas is at atmospheric pressure, e.g. ambient air, thus obviating the need for vacuum chambers and pumps. Various aspects concerning the inactivation of food-borne pathogens using cold plasma technology have been reviewed by Misra et al. (2011b) and Niemira (2012). Until recent advances in the development and applications of atmospheric pressure plasma systems, cold plasma processes were carried out under vacuum and thus incompatible with food processing.

While cold plasmas are used in industrial processes such as electronics cleaning (Korner et al., 1995), bonding of plastics (Vlachopoulou et al., 2009) or binding of dye to textile fibres (Naebe et al., 2010), their potential remains untapped in the food industry. Plasma generation at atmospheric pressure is of interest, both technically and commercially to the food industries because this can be implemented at ambient conditions, reduces cost, increases treatment speed and enables industrial applicability (Misra et al., 2011b).

The present study involves use of a dielectric barrier discharge (DBD) to generate cold plasma from humid atmospheric air inside a package. DBD is a well-established technique to generate ACP plasma 
(Kogelschatz, 2003) and has attracted the interest of a range of scientists in recent years because of its unique advantages (Xu, 2001; Huang et al., 2010). In this work, an evaluation of the potential use of atmospheric air cold plasma for the decontamination of strawberries inside a closed package was conducted. Some of the discharge features were obtained from charge-voltage $(\mathrm{Q}-\mathrm{V})$ and currentvoltage (I-V) measurements. The quality of the treated produce was evaluated based on the strawberry respiration rate within a closed system and change in colour and firmness.

\section{Materials and methods}

\subsection{Produce Characteristics}

Fresh strawberries (Fragaria ananasa, var. Elsanta) were purchased from the local wholesale fruit market (Dublin, Ireland) and stored under refrigerated conditions for 1 hour before the beginning of the experiments. The density of the strawberries was determined by the volume displacement method using toluene instead of water, to avoid floating (AOAC, 1998). The choice of toluene was also based on the fact that it interacts to a lesser extent with the fruit (Ferrando and Spiess, 2003) and can efficiently fill the shallow dips of strawberries due to its low surface tension. The temperature of the liquid was registered using a thermometer to be $20.0 \pm 0.2^{\circ} \mathrm{C}$. The mean density of the strawberry samples was found to be $0.938 \pm 0.004 \mathrm{gcm}^{-3}$ and was used in the calculations for respiration rate.

\subsection{In-package plasma treatment}

\section{[Insert Figure 1 here]}

A schematic of the experimental set-up employed in the study is presented in Figure 1. The DBD system comprises of two circular aluminium plate electrodes (outer diameter $=158 \mathrm{~mm}$ ) over polypropylene (PP) dielectric layers (of $2 \mathrm{~mm}$ thickness) between which a PP package containing the food sample is placed. The high voltage step-up transformer (Phenix Technologies, Inc., USA) 
powered at $230 \mathrm{~V}, 50 \mathrm{~Hz}$ delivers a high voltage output in the range $0-120 \mathrm{kV} \mathrm{rms}$. A single value of the voltage applied across the electrodes of $60 \mathrm{kV}_{\mathrm{RMS}}$ at $50 \mathrm{~Hz}$ was used for these experiments. The rigid PP package had dimensions of $310 \mathrm{~mm} \times 230 \mathrm{~mm} \times 40 \mathrm{~mm}$ and also served as a dielectric material. Boxes with strawberry samples were sealed inside polymeric film of 50 micrometres thickness (Cryovac BB3050) with very low gas transmission rates, in order to prevent leakage of the plasma-generated reactive species. This film served as an additional layer of dielectric. The atmospheric air condition at the time of packaging and treatment was $42 \%$ relative humidity (RH) and $25^{\circ} \mathrm{C}$, as measured using a humidity-temperature probe connected to a data logger (Testo 176 T2, Testo Ltd., UK). The strawberry samples were subjected to indirect ACP treatment for 5 minute and subsequently stored for 24 hours at $10{ }^{\circ} \mathrm{C}$ and $90 \% \mathrm{RH}$. Indirect exposure refers to placement of strawberries away from area of field between electrodes (at least $2.5 \mathrm{~cm}$ from the circumference of field in this study). These operating conditions were selected based on previous experiments conducted in our laboratory. All treatments and further evaluations were done in triplicate.

\subsection{Electrical characterisation of the plasma}

The electrode bias voltage was monitored using a high voltage probe (North Star PVM-6) coupled to a 10:1 voltage divider to allow recording of the full voltage waveforms on an Agilent InfiniVision 2000 X-Series Oscilloscope (Agilent Technologies Inc., USA). The discharge characteristics were monitored using Q-V measurements by connecting a capacitor $\mathrm{C}_{0}=8.8 \mathrm{nF}$ in series on the ground side of the discharge. The voltage drop across the capacitor was recorded using a 1000:1 high voltage probe (Testec-Electronik TT-HVP 15kV), while a current transformer probe (Bergoz CT-E1.0S)

was used to measure the current waveforms. The charge on the capacitor was plotted versus the applied voltage to obtain Lissajous figures from which the capacitance of the discharge gap, the capacitance of the dielectric, the total power delivered to the plasma, the transferred charge and discharge-on time (duration of the discharge per half cycle) were calculated, respectively. 


\subsection{Measurement of ozone concentration}

Ozone concentrations within the package were measured, immediately following ACP treatments, using Gastec short-term ozone detection tubes (Product No. 18M, Gastec, Japan). These tubes contain a reagent which changes colour after coming in contact with the specified gas and are calibrated for specific sampling volumes. $10 \mathrm{~mL}$ of gas was pulled out of the package, through the tube, using a gas pump (Gastec, Japan) and a hypodermic needle. To avoid leakage of the gas, a silicone septum with adhesive was used at the point of gas sampling.

\subsection{Microbial enumeration}

For microbial count estimations, untreated control samples, untreated control samples stored at $10^{\circ}$ $\mathrm{C}$ for $24 \mathrm{~h}$ and atmospheric cold plasma (ACP) treated samples stored at $10^{\circ} \mathrm{C}$ for $24 \mathrm{~h}$ were analysed, respectively. Strawberry samples were placed in stomacher ${ }^{\circledast}$ bags (Seward 80 bags, UK), two strawberries (weighing approximately 10-15 g) were placed in each separate bag, containing 10 $\mathrm{ml}$ of sterile maximum recovery diluent (MRD, Scharlau Chemie, Spain) and hand rubbed for 2-3 min. The resulting wash fluid was serially diluted in MRD. Total aerobic mesophiles and yeasts/moulds count were determined by surface plating of appropriate aliquots in duplicate on plate count agar (PCA, Scharlau Chemie, Spain) and potato dextrose agar (PDA, Scharlau Chemie, Spain) respectively. PCA plates were incubated at $37^{\circ} \mathrm{C}$ for $24-48 \mathrm{~h}$. The PDA plates were incubated at $25^{\circ} \mathrm{C}$ for $3-7$ days before yeast/mould colonies were counted. All experiments were conducted in duplicate and each microbial count was the mean of four determinations.

\subsection{Respiration rate measurement}

After $24 \mathrm{~h}$ in-pack storage, ACP treated strawberries were carefully moved into a gas jar (2.365 litre volume), sealed to air tight conditions and stored at $10{ }^{\circ} \mathrm{C}$ and $90 \%$ relative humidity (RH). The recommended storage conditions for strawberries are $0-5{ }^{\circ} \mathrm{C}$ and $\sim 95 \% \mathrm{RH}$. However, the conditions employed in the present study were selected to account for the temperature abuse that is 
commonly encountered during transport and in displays at retail. The change in $\mathrm{O}_{2}$ and $\mathrm{CO}_{2}$ gas compositions inside the respirometer were monitored over time using a gas analyser (Systech Instruments, UK). Gas sampling was performed with a hypodermic needle, inserted through an adhesive septum previously fixed to the jar, at a flow rate of $150 \mathrm{~mL} / \mathrm{min}$ for $10 \mathrm{~s}$. The instrument is based on electrochemical sensor to record $\mathrm{O}_{2}$ concentration and on a mini-IR spectrophotometer to record $\mathrm{CO}_{2}$ concentrations (accuracy: $0.1 \% \mathrm{v} / \mathrm{v} \mathrm{O}_{2} ; 2 \% \mathrm{v} / \mathrm{v} \mathrm{CO}_{2}$ ). Initial experiments showed that sampling had no significant influence on gas concentration in the jar, as the total volume of the jar was much greater than the total volume sampled by the instrument during the experiment.

Two-parameter, non-exponential equations (1), (2) similar to the Peleg's model (Peleg, 1988) were respectively fitted to the average $\mathrm{O}_{2}$ and $\mathrm{CO}_{2}$ concentrations of the control and treated packages at different storage time $t$ (in hours), using nonlinear regression analysis.

$$
\begin{gathered}
{\left[O_{2}\right]=0.21-\left[\frac{t}{K_{1} t+K_{2}}\right]} \\
{\left[\mathrm{CO}_{2}\right]=\frac{t}{K_{1} t+K_{2}}}
\end{gathered}
$$

where $K_{1}$ and $K_{2}$ are the regression coefficients. A similar model has been applied for respiration data of apples by Mahajan and Goswami (2001) and Bhande et al. (2008).

The rate of change of gas concentration was determined from the first derivative of the regression functions as outlined in Equations (3) and (4):

$$
\begin{aligned}
& \frac{d\left[C O_{2}\right]}{d t}=-K_{1} t\left(K_{1} t+K_{2}\right)^{-2}+\left(K_{1} t+K_{2}\right)^{-1} \\
& \frac{d\left[O_{2}\right]}{d t}=K_{1} t\left(K_{1} t+K_{2}\right)^{-2}-\left(K_{1} t+K_{2}\right)^{-1}
\end{aligned}
$$


At each sampling time, the respiration rates $R_{\mathrm{CO}_{2}}$ and $R_{\mathrm{O}_{2}}$, defined in terms of $\mathrm{CO}_{2}$ evolution and $\mathrm{O}_{2}$ consumption, were calculated using Equations (5) and (6), respectively.

$$
\begin{aligned}
& R_{\mathrm{CO}_{2}}=\frac{d\left[\mathrm{CO}_{2}\right]}{d t} \frac{\mathrm{V}}{W} \\
& R_{\mathrm{O}_{2}}=-\frac{d\left[\mathrm{O}_{2}\right]}{d t} \frac{\mathrm{V}}{W}
\end{aligned}
$$

where $V$ and $W$ are the free gas volume $(\mathrm{mL})$ and weight of the strawberries $(\mathrm{kg})$, respectively.

\subsection{Colour measurement}

The colour was quantified using a L*-a*-b* colorimeter (Colour Quest XE Hunter Lab, Northants, UK). The colour measurements were performed along four symmetrical sections on each strawberry and the average value is reported. The instrument was calibrated using white $\left(L^{*}=93.97, a^{*}=0.88\right.$ and $\left.b^{*}=1.21\right)$ and green $\left(L^{*}=56.23, a^{*}=21.85, b^{*}=8.31\right)$ standard tiles, respectively. Hunter colour readings were recorded. The $L^{*}$ parameter (lightness index scale) ranges from 0 (black) to 100 (white). The parameter $a^{*}$ measures the degree of red $(+a)$ or green $\left(-a^{*}\right)$ colour and the $b^{*}$ parameter measures the degree of yellow $(+b)$ or blue $\left(-b^{*}\right)$ colour.

\subsection{Firmness}

Four strawberries from each of the control and ACP treated groups were measured. The force necessary to cause a deformation of $3 \mathrm{~mm}$ with a speed of $0.2 \mathrm{~mm} / \mathrm{s}$ was recorded using an Instron texture analyser (Instron 4302 Universal Testing Machine, Canton, MA, USA), with a 3.5-mmdiameter flat-faced cylindrical probe. Data were analysed with the Instron series IX software for Windows. 


\subsection{Statistical Analysis}

The non-linear regressions were carried out using the Gauss-Newton numerical method available from the Minitab software package (Minitab ${ }^{\circledR}$ ver. 16 , Minitab Ltd.). The coefficient of determination $\left(r^{2}\right)$ and the root mean squared error (RMSE), defined by equation (7) below, were used as criterion to evaluate the adequacy of model fitting.

$$
R M S E=\sqrt{\sum_{i=1}^{n_{t}} \frac{\left(y_{\text {expi }}-y_{\text {pred }}\right)^{2}}{n_{t}-n_{p}}} \text { (7) }
$$

where $y_{\exp i}$ are experimental observations, $y_{\text {pred }}$ are model predictions, $n_{t}$ are number of experimental data points and $n_{p}$ are number of estimated model parameters. One-way ANOVA was performed to determine the significance of differences among the colour parameters and firmness of control and treated strawberries at $95 \%$ level of confidence.

\section{Results and Discussion}

\subsection{Discharge characteristics}

The I-V waveforms and the Q-V characteristics for the discharge with and without strawberries are shown in figures $2(a, b)$ and $3(a, b)$, respectively. The I-V waveforms indicate the presence of a filamentary-type discharge without noticeable differences between the empty package and the package with produce. The use of high voltage permits generation of a stable discharge, even at large gaps of $4 \mathrm{~cm}$. The $Q-V$ characteristics of figure $3(a, b)$ take the shape of closed-loop parallelograms, where along the sides A-B and C-D the discharge is idle while during B-C and D-A it goes through breakdown transferring charges trough the gap for applied voltage values between $\mathrm{V}_{\text {min }}$ (corresponding to breakdown voltage) and $\mathrm{V}_{\mathrm{p}}$ (peak voltage).

[Insert Figure 2 (a) and (b) here] 
The electrical performances of the discharge derived from the $Q-V$ measurements according to the method developed by Manley (1943), Falkenstein and Coogan (1997) are shown in Table 1[Insert Table, where $C_{d}$ is the dielectric capacitance, $C_{g a p}$ is the capacitance of the discharge gap, $\mathrm{P}$ is the discharge power, $\Delta Q$ is the total charge transported over a cycle and $\Delta t$ is the duration of the discharges per half voltage cycle. The capacitances are calculated from the slopes of the Q-V parallelogram obtained as Lissajous figure with $C_{d}$ and $C_{\text {cell }}$ (total capacitance of the discharge cell) indicated in Figure $3(\mathrm{a}, \mathrm{b})$ while $C_{g a p}$ is given by $C_{g a p}=\frac{C_{d} \times C_{\text {cell }}}{\left(C_{d}-C_{c e l l}\right)}$. The transported charge is calculated as $\Delta Q=2 . C_{0} \cdot Q$; and $\Delta t=\frac{1}{2 \pi f}\left[\pi / 2-\sin ^{-1}\left(\frac{V_{\min }}{V_{p}}\right)\right]$ with $C_{0}$ the measurement capacitor, $\mathrm{f}$ the frequency $(50 \mathrm{~Hz})$ and $V_{\min }$ the breakdown voltage, $V_{p}$ the peak voltage and charge $Q$ indicated in Figure $3 \mathrm{~b}$. The discharge power is calculated as the product of the area of the Lissajous charge-voltage loop and the frequency of applied voltage. The discharge performance is not affected in any way by the presence of fresh produce as electrical parameters for the box with and without produce have close values, within the range of estimation errors.

\section{[Insert Table 1 here]}

\section{[Insert Figure 3 here]}

\subsection{Ozone concentrations}

When high voltage is applied across the electrodes, the electric field generated produces the phenomenon of dielectric barrier discharge (DBD) (Amjad et al., 2012; Kogelschatz, 2003; Kogelschatz et al., 1997). This discharge generates energetic electrons that dissociate oxygen molecules by direct impact. The single $\mathrm{O}$ atom from the dissociation combines with oxygen molecule $\left(\mathrm{O}_{2}\right)$ to form ozone gas. Ozone is considered as one of the most chemically stable and active species generated in DBD because of its relatively long lifetime and high oxidation potential. Ozone 
concentrations, inside the package containing strawberries, were measured to be $(1000 \pm 100) \mathrm{ppm}$ immediately post-treatment. We have observed that ozone concentration, generated in similar conditions but without strawberries, can be as high as $(1500 \pm 100)$ ppm after $2 \mathrm{~min}$. The comparatively lower ozone concentration for packages loaded with product could be due to the ozone solubilising by reacting with the water at the produce surface and also the smaller volume of available air in the produce packages, i.e. lower initial volume of oxygen. It is worth noting that ozone has been granted GRAS (generally recognized as safe) status by the U.S. Food and Drug Administration as a direct additive to food (FDA, 2001; Rice and Graham, 2001). Besides ozone, the plasma apparatus employed here has also been found to generate reactive nitrogen species (Misra et al., 2013).

\subsection{Microbial inactivation}

The total mesophilic and yeasts/mould counts for untreated samples were 4.99 and $4.96 \log _{10} \mathrm{cfu} / \mathrm{g}$, respectively. The storage at $10^{\circ} \mathrm{C}$ for $24 \mathrm{~h}$ of untreated control samples had no effect on the reduction of viable population on strawberry surfaces, where the total mesophilic count recorded was $4.92 \log _{10} \mathrm{cfu} / \mathrm{g}$. Yeast and mould counts also showed similar trend and was $5.06 \log _{10} \mathrm{cfu} / \mathrm{g}$. The effect of ACP treatment on the reduction of total mesophiles and yeasts/moulds on strawberry surface is shown in Table 2[Insert Table . In-package, indirect ACP treatment of strawberries for 5 min achieved reductions of 2.4 and $3.3 \log$ cycles of total mesophiles and surface yeasts/moulds, respectively.

\section{[Insert Table 2 here]}

Critzer et al. (2007) have also reported the ability of atmospheric plasma for reduction of inoculated microbial populations on fresh produce surfaces. Recently, Fernandez et al. (2013) investigated cold atmospheric gas plasma inactivation of Salmonella enterica serovar Typhimurium on fresh produce. The reported study achieved $2.72,1.76$ and 0.94 log-reductions of S. Typhimurium on lettuce, 
strawberry and potato, respectively, in 15 min of plasma treatment time. The type of produce and its intrinsic characteristics like waxy cuticles, stomata of lettuce and the convolutions of strawberry surfaces were suggested to contribute to different inactivation rates. Similarly, Perni et al. (2008) observed a reduced efficacy of ACP in inactivating bacteria and yeast inoculated on freshly cut fruit surfaces compared to that on inert filter membranes.

In this work reductions in total mesophiles and yeasts/moulds were found, which are primary contributors to spoilage. The efficient reduction of microorganism in a sealed package suggests the elimination of a possible post-process contamination of the treated products. The fact that temperatures that could cause microbial inactivation were never reached, suggests that the microbial reductions were solely due to unique chemical species obtained in plasma state (Pankaj et al., 2013). This was verified using a handheld infrared thermometer (IR-102, Maplin Electronics, UK) which recorded a maximum rise of $8 \pm 2{ }^{\circ} \mathrm{C}$ after 5 minute of treatment. Previous studies in our laboratory have revealed absence of any residual ozone after at least $24 \mathrm{~h}$ post-treatment, under ambient room temperature conditions (Misra et al., 2012). Therefore, it is likely that active species of ACP, including ozone, are retained inside the package for varying times, dependent on the species lifetime, leading to significant reductions in microbial load. However, this requires further investigation into the kinetics of degradation of post-plasma gaseous species inside the sealed package.

\subsection{Respiration rate of cold plasma treated strawberries}

It is well-known that processing of fresh horticultural produce promotes a faster physiological deterioration, biochemical changes and microbial degradation of the product even when only mild processing operations are used (O'Beirne and Francis, 2003; Rico et al., 2007). This is because fresh produce is often subjected to stress during the processing steps (Watada et al., 1996). When a treatment process damages the tissue or induces stress in the produce, it exhibits a higher respiration rate during processing which can even last after the completion of the process (Laties, 
1978; Mitcham and McDonald, 1993). Practical experience reveals that tissues with high respiratory rates and/or low energy reserves have shorter postharvest lives (Eskin, 1990).

In this study, the respiration rate was observed to decrease with time for control as well as treated strawberries (figure 4, 5 and Table 3). This decline is due to the decreasing $\mathrm{O}_{2}$ concentration and increasing $\mathrm{CO}_{2}$ concentration in the gaseous environment. The respiration rate of the treated produce was found to be lower than that of the control following an initial delay which is most likely due to the decreased microbial count. Based on these observations it can be said that ACP does not induce significant stress in strawberries treated within the set of conditions employed.

\section{[Insert Figure 4 here]}

\section{[Insert Table 3 here]}

\section{[Insert Figure 5 here]}

\section{5. $L^{*}-a *-b *$ colour of strawberries}

Colour is the most obvious parameter for consumers (Del-Valle et al., 2005) and plays a key role in food choice, food preference and acceptability, and may even influence taste thresholds, sweetness perception and pleasantness (Clydesdale, 1993). A change in the $L^{*}-a^{*}-b^{*}$ colour parameters of ACP treated strawberries was observed (Figure 7). However, the changes in individual colour parameters viz. lightness, redness or greenness were statistically insignificant $(p>0.05)$ in comparison to the untreated control stored under same conditions.

\section{[Insert Figure 6 here]}

\subsection{Firmness}

Texture is a critical quality attribute in the consumer acceptability of fresh fruits. The firmness of control, untreated strawberries stored at $10{ }^{\circ} \mathrm{C}$ for $24 \mathrm{hr}$ as well as for ACP treated strawberries are 
shown in figure 8. A significant $(p \leq 0.05)$ decrease in firmness of strawberries was recorded within 24hr. The difference in firmness among untreated control and treated group was found to be statistically insignificant ( $p>0.05)$. Strawberry is a soft fruit that suffers a rapid loss of firmness during storage, which contributes greatly to its short postharvest life and susceptibility to fungal contamination (Hernández-Muñoz et al., 2008). Furthermore, the ability of ozone to retain the texture of strawberries has already been reported in the literature (Runguang, 2011). Besides instrumental colour and firmness, no obvious change in the flavour or edible quality of the strawberries relative to control was noticed.

\section{[Insert Figure 7 here]}

\section{Conclusions}

In-package decontamination of fresh foods is desirable as this minimises the possibility of postprocessing contamination. In order to achieve this, atmospheric cold plasma was generated inside a sealed package containing strawberries, using a dielectric barrier discharge in the filamentary regime. The electrical characteristics of the discharge were diagnosed using Q-V measurements and indicated that the discharge behaviour and performance are not affected by the presence of the produce.

The behaviour of plasma, its action on micro-organisms and the resulting changes in food quality are largely determined by the plasma chemistry. Plasma chemistry and the resultant dynamics can be very complex involving a large number of different species at any given point of time. For example chemistry of plasma in air is believed to comprise of more than 75 species and almost 500 reactions (Gordillo-Vázquez, 2008). These active species of post-plasma discharge inactivate the microorganisms before reverting back to their original or stable states (Ziuzina et al., 2013). Although the modified gas composition induced through complex plasma chemistry may persists for several hours $(<24 \mathrm{~h})$ inside the package, a drastic change in respiration rate of strawberries does not occur. Thus, 
this work demonstrates the ability of in-package ACP to reduce the background microflora present on strawberries without inducing significant physiological (respiratory) stress or adversely affecting the colour and firmness. The DBD system achieved these desired effects with a power input of only $15-20 \mathrm{~W}$, without increasing the temperature of the samples significantly.

Future studies will focus on inactivation of inoculated bacteria inoculated on surface of fresh produce. Additionally, in order to assess the long term effects of ACP on food quality, shelf-life studies will be conducted.

\section{Acknowledgements}

The research leading to these results has received funding from the European Community's Seventh Framework Programme (FP7/2007-2013) under grant agreement number 285820. The authors also acknowledge support from the Irish Research Council (IRC). 


\section{References}

Amjad, M., Salam, Z., Facta, M., Ishaque, K., (2012). A Simple and Effective Method to Estimate the Model Parameters of Dielectric Barrier Discharge Ozone Chamber. Instrumentation and Measurement, IEEE Transactions on(99), 1-8.

AOAC, (1998). Official methods of analysis of the Association of Official Analytical Chemists. Association of Official Analytical Chemists, Washington DC.

Bhande, S., Ravindra, M., Goswami, T., (2008). Respiration rate of banana fruit under aerobic conditions at different storage temperatures. Journal of Food Engineering 87(1), 116-123.

Castenmiller, J., Fenwick, R., Lindsay, D., Maat, J. (2008). European Technology Platform on Food for Life- Implementation Action Plan. Confederation of the food and drink industry of EU (CIAA), pp 561.

Clydesdale, F.M., (1993). Color as a factor in food choice. Critical Reviews in Food Science \& Nutrition 33(1), 83-101.

Critzer, F., Kelly-Wintenberg, K., South, S., Golden, D., (2007). Atmospheric plasma inactivation of foodborne pathogens on fresh produce surfaces. Journal of Food Protection 70(10), 2290.

Deliza, R., Rosenthal, A., Silva, A.L.S., (2003). Consumer attitude towards information on non conventional technology. Trends in Food Science \& Technology 14(1-2), 43-49. 
Del-Valle, V., Hernández-Muñoz, P., Guarda, A., Galotto, M.J., (2005). Development of a cactusmucilage edible coating (Opuntia ficus indica) and its application to extend strawberry (Fragaria ananassa) shelf-life. Food Chemistry 91(4), 751-756.

Deora, N.S., Misra, N.N., Deswal, A., Mishra, H.N., Cullen, P.J., Tiwari, B.K., (2013). Ultrasound for Improved Crystallisation in Food Processing. Food Engineering Reviews 5(1), 36-44.

Eskin, M.N.A., (1990). Biochemical changes in raw foods: fruits and vegetables, in: Eskin, M.N.A. (Ed.), Biochemistry of foods. Academic Press, Inc., Toronto, ON, pp. 70-78.

EU Directive 2092/91 (1991). On organic production of agricultural products and indications referring thereto on agricultural products and foodstuffs. Council regulation (EEC) No. 2092/91.

Falkenstein, Z., Coogan, J.J., (1997). Microdischarge behaviour in the silent discharge of nitrogen oxygen and water - air mixtures. Journal of Physics D: Applied Physics 30(5), 817.

FDA, U., (2001). Secondary direct food additives permitted in food for human consumption. Federal Register 66(123), 33829-33830.

Fernandez, A., Noriega, E., Thompson, A., (2013). Inactivation of Salmonella enterica serovar Typhimurium on fresh produce by cold atmospheric gas plasma technology. Food Microbiology 33(1), 24-29.

Ferrando, M., Spiess, W.E.L., (2003). Mass Transfer in Strawberry Tissue During Osmotic Treatment II: Structure-function Relationships. Journal of Food Science 68(4), 1356-1364. 
Garcia, L.C., Pereira, L.M., Luca Sarantópoulos, C.I.G., Hubinger, M.D., (2011). Effect of Antimicrobial Starch Edible Coating on Shelf-Life of Fresh Strawberries. Packaging Technology and Science 25(7), 413-425.

Gómez-López, V.M., Ragaert, P., Debevere, J., Devlieghere, F., (2007). Pulsed light for food decontamination: a review. Trends in Food Science \& Technology 18(9), 464-473.

Gordillo-Vázquez, F.J., (2008). Air plasma kinetics under the influence of sprites. Journal of Physics D: Applied Physics 41(23), 234016.

Hernández-Muñoz, P., Almenar, E., Valle, V.D., Velez, D., Gavara, R., (2008). Effect of chitosan coating combined with postharvest calcium treatment on strawberry (Fragaria $\mathrm{x}$ ananassa) quality during refrigerated storage. Food Chemistry 110(2), 428-435.

Huang, F., Chen, L., Wang, H., Yan, Z., (2010). Analysis of the degradation mechanism of methylene blue by atmospheric pressure dielectric barrier discharge plasma. Chemical Engineering Journal 162(1), 250-256.

Hugas, M., Garriga, M., Monfort, J.M., (2002). New mild technologies in meat processing: high pressure as a model technology. Meat Science 62(3), 359-371.

Jeyamkondan, S., Jayas, D.S., Holley, R.A., (1999). Pulsed electric field processing of foods: a review. Journal of Food Protection 62, 1088-1096.

Kogelschatz, U., (2003). Dielectric-barrier discharges: Their history, discharge physics, and industrial applications. Plasma Chemistry and Plasma Processing 23(1), 1-46. 
Kogelschatz, U., Eliasson, B., Egli, W., (1997). Dielectric-barrier discharges. Principle and applications. Journal de physique. IV 7(C4), 47-66.

Korner, N., Beck, E., Dommann, A., Onda, N., Ramm, J., (1995). Hydrogen plasma chemical cleaning of metallic substrates and silicon wafers. Surface and Coatings Technology 76-77(2), 731-737.

Laties, G., (1978). The development and control of respiratory pathways in slices of plant storage organs. Biochemistry of wounded plant tissues. Walter de Gruyter, New York, 421-466.

Mahajan, P., Goswami, T., (2001). PH-Postharvest Technology-Enzyme Kinetics Based Modelling of Respiration Rate for Apple. Journal of Agricultural Engineering Research 79(4), 399-406.

Manley, T., (1943). The electric characteristics of the ozonator discharge. Transactions of the Electrochemical Society 84(1), 83-96.

Misra, N.N., Kadam, S.U., Pankaj, S.K., (2011a). An overview of nonthermal technologies in food processing. Indian Food Industry 30(5-6), 45-52.

Misra, N.N., Tiwari, B.K., Raghavarao, K.S.M.S., Cullen, P.J., (2011b). Nonthermal Plasma Inactivation of Food-Borne Pathogens. Food Engineering Reviews 3(3-4), 159-170.

Misra, N.N., Ziuzina, D., Cullen, P.J., Keener, K.M. (2013). Characterization of a novel atmospheric air cold plasma system for treatment of packaged biomaterials. Transactions of the ASABE 56(3), 10111016. 
Mitcham, E.J., McDonald, R.E., (1993). Respiration rate, internal atmosphere, and ethanol and acetaldehyde accumulation in heat-treated mango fruit. Postharvest Biology and Technology 3(1), $77-86$.

Naebe, M., Cookson, P.J., Rippon, J., Brady, R.P., Wang, X., Brack, N., Van, G. (2010). Effects of Plasma Treatment of Wool on the Uptake of Sulfonated Dyes with Different Hydrophobic Properties. Textile Research Journal 80(4), 312-324.

Narciso, J.A., Baldwin, E.A., Plotto, A., Ference, C.M., (2007). Preharvest Peroxyacetic Acid Sprays Slow Decay and Extend Shelf Life of Strawberries. HortScience 42(3), 617-621.

Nguyen-the, C., Carlin, F., (1994). The microbiology of minimally processed fresh fruits and vegetables. Critical Reviews Food Science \& Nutrition 34(4), 371-401.

Niemira, B.A., (2012). Cold Plasma Decontamination of Foods. Annual Review of Food Science and Technology 3(1), 125-142.

O’Beirne, D., Francis, G., (2003). Reducing pathogen risks in MAP-prepared produce, in: Ahvenainen, R. (Ed.), Novel food packaging techniques. Boca Raton, FL: Woodhead Publishing Limited/CRC Press LLC, Cambridge, UK, pp. 231-286.

Pangloli, P., Hung, Y.-C., (2013). Reducing microbiological safety risk on blueberries through innovative washing technologies. Food Control 32(2), 621-625. 
Pankaj, S.K., Misra, N.N., Cullen, P.J. (2013). Kinetics of tomato peroxidase inactivation by atmospheric pressure cold plasma based on dielectric barrier discharge. Innovative Food Science and Emerging Technologies, http://dx.doi.org/10.1016/j.ifset.2013.03.001

Peleg, M., (1988). An empirical model for the description of moisture sorption curves. Journal of Food Science 53(4), 1216-1217.

Perni, S., Shama, G., Kong, M.G., (2008). Cold Atmospheric Plasma Disinfection of Cut Fruit Surfaces Contaminated with Migrating Microorganisms. Journal of Food Protection 71(8), 1619-1625.

Ramos, B., Miller, F.A., Brandão, T.R.S., Teixeira, P., Silva, C.L.M., (2013). Fresh fruits and vegetables An overview on applied methodologies to improve its quality and safety. Innovative Food Science \& Emerging Technologies.

Rice, R.G., Graham, D.M., (2001). US FDA regulatory approval of ozone as an antimicrobial agentwhat is allowed and what needs to be understood. Ozone News 29(5), 22-31.

Rico, D., Martín-Diana, A.B., Barat, J.M., Barry-Ryan, C., (2007). Extending and measuring the quality of fresh-cut fruit and vegetables: a review. Trends in Food Science and Technology 18(7), 373-386.

Runguang, Z., (2011). Effect of Ozone Treatment on the Quality of Strawberry Fruit during Storage. Academic Periodical of Farm Products Processing 7, 007.

Suzuki, A., (2002). High pressure-processed foods in Japan and the world, in: Rikimaru, H. (Ed.), Progress in Biotechnology. Elsevier, pp. 365-374. 
Vlachopoulou, M-E., Tserepi, A., Pavli, P., Argitis, P., Sanopoulou, M., Misiakos, K., (2009). A low temperature surface modification assisted method for bonding plastic substrates. Journal of Micromechanics and Microengineering 19(1), 015007.

Watada, A.E., Ko, N.P., Minott, D.A., (1996). Factors affecting quality of fresh-cut horticultural products. Postharvest Biology and Technology 9(2), 115-125.

Xu, X., (2001). Dielectric barrier discharge - properties and applications. Thin Solid Films 390(1-2), $237-242$.

Ziuzina, D., Patil, S., Cullen, P. J., Keener, K. M., Bourke, P., (2013). Atmospheric cold plasma inactivation of Escherichia coli in liquid media inside a sealed package. Journal of Applied Microbiology 114(3), 778-787. 


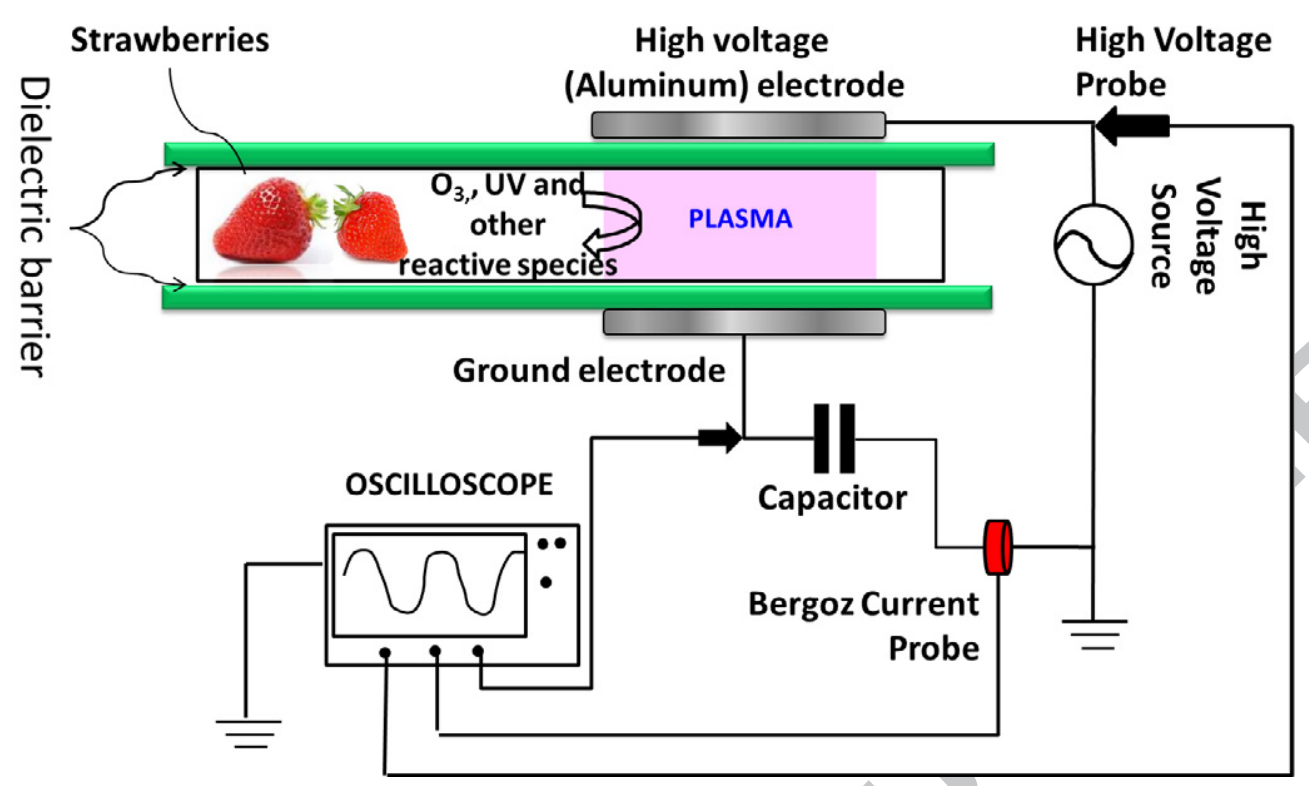

Figure 1 


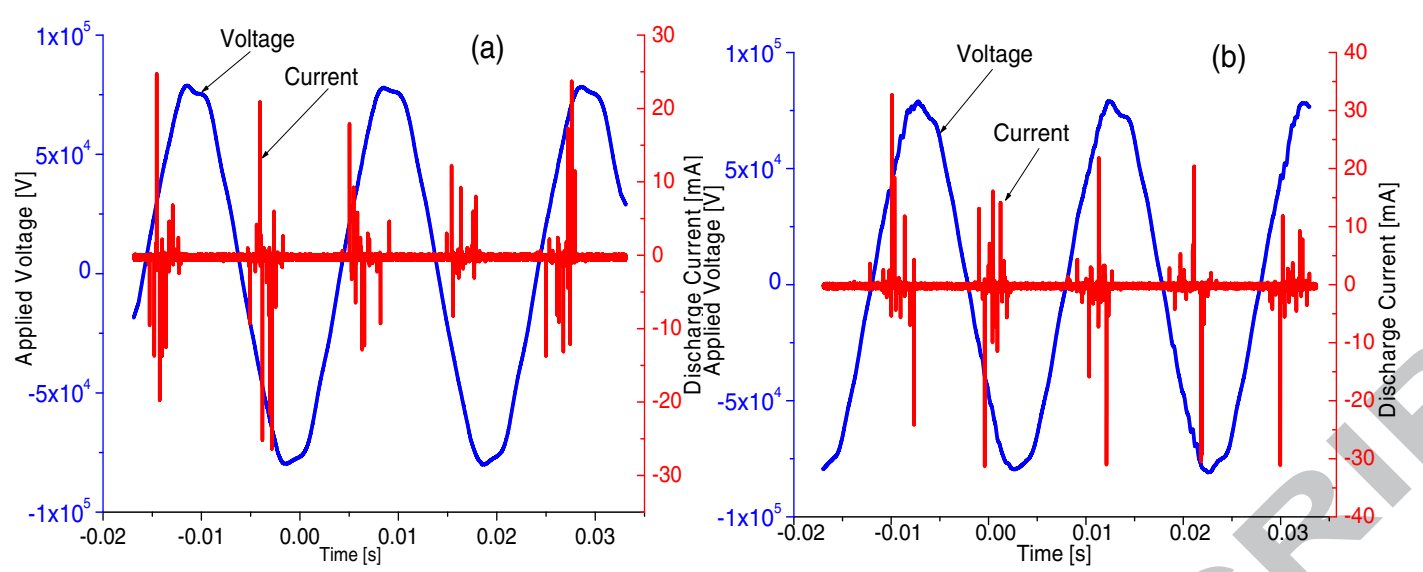

Figure 2 (a) and 2(b) 

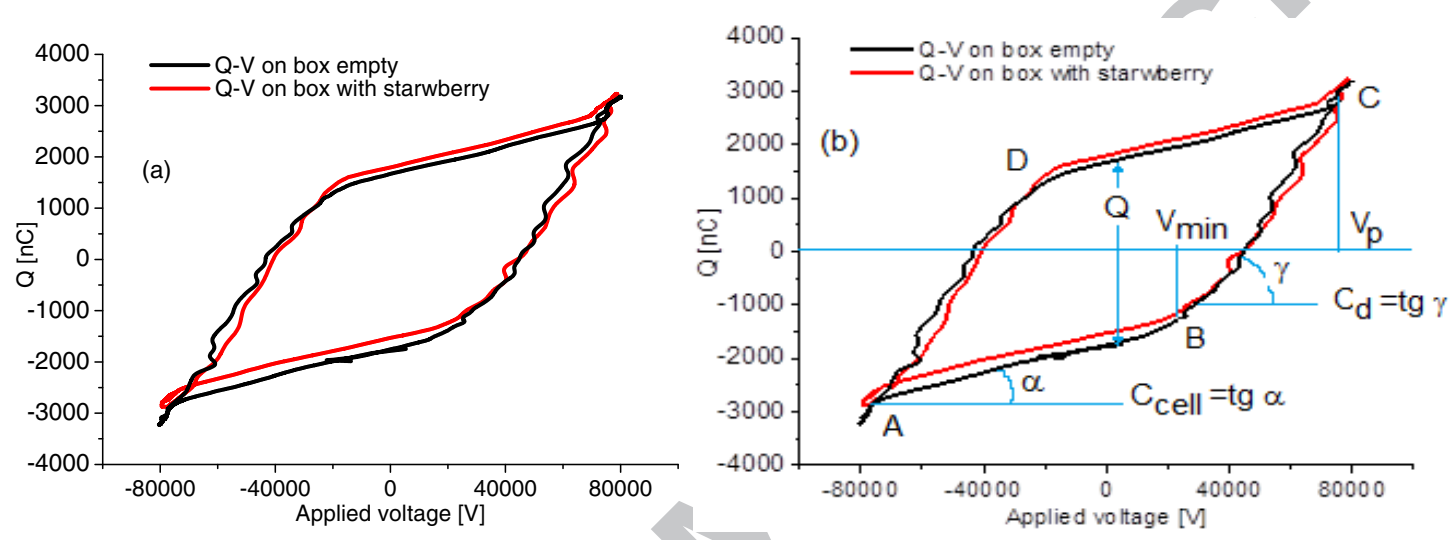

Figure 3 


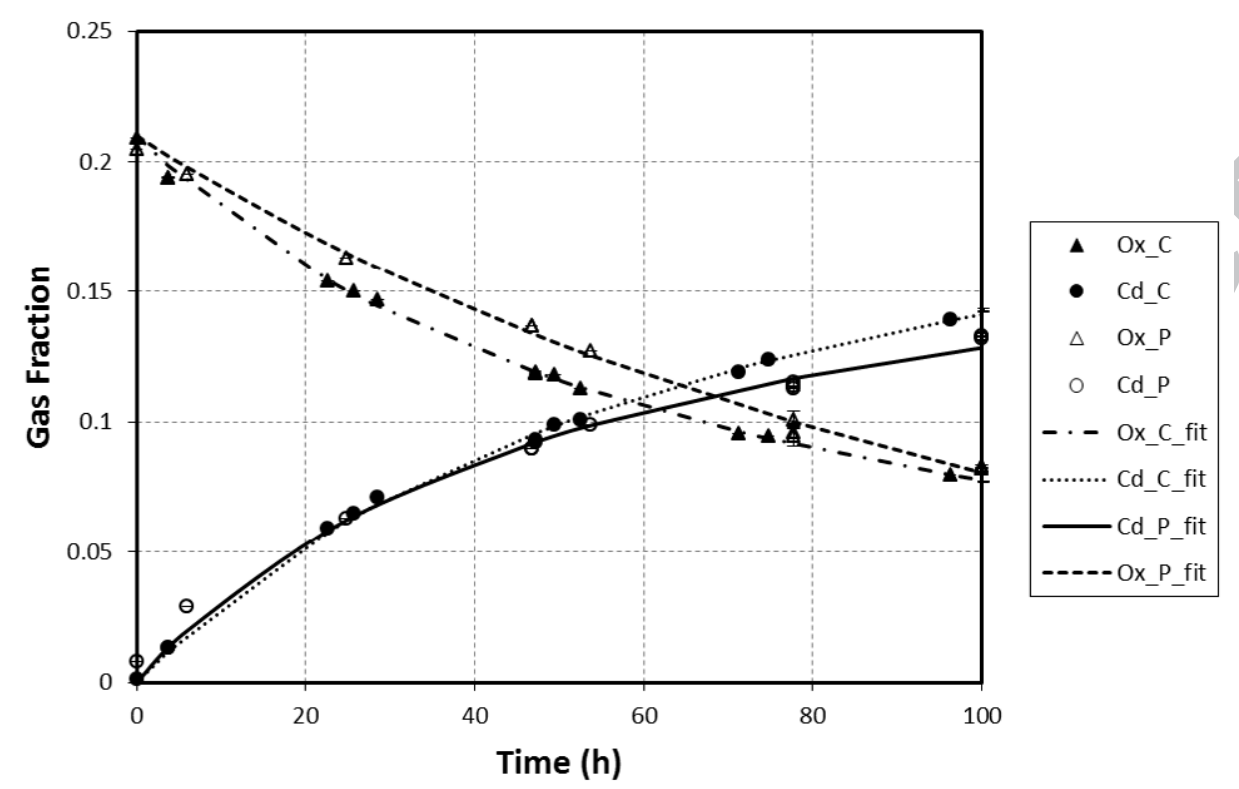

Figure 4 


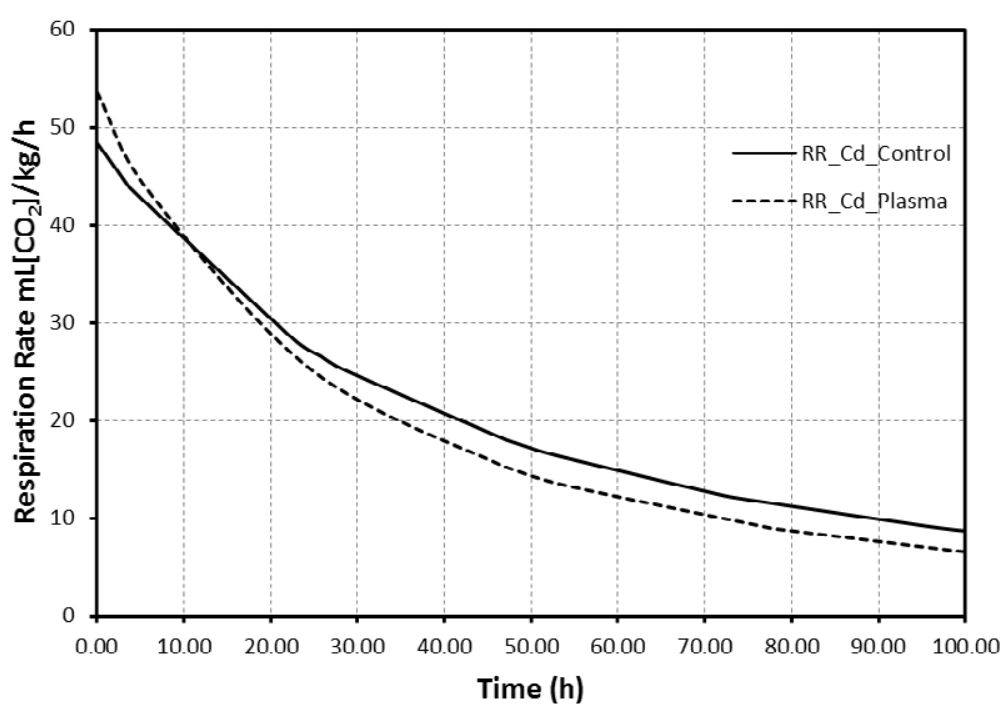

Figure 5

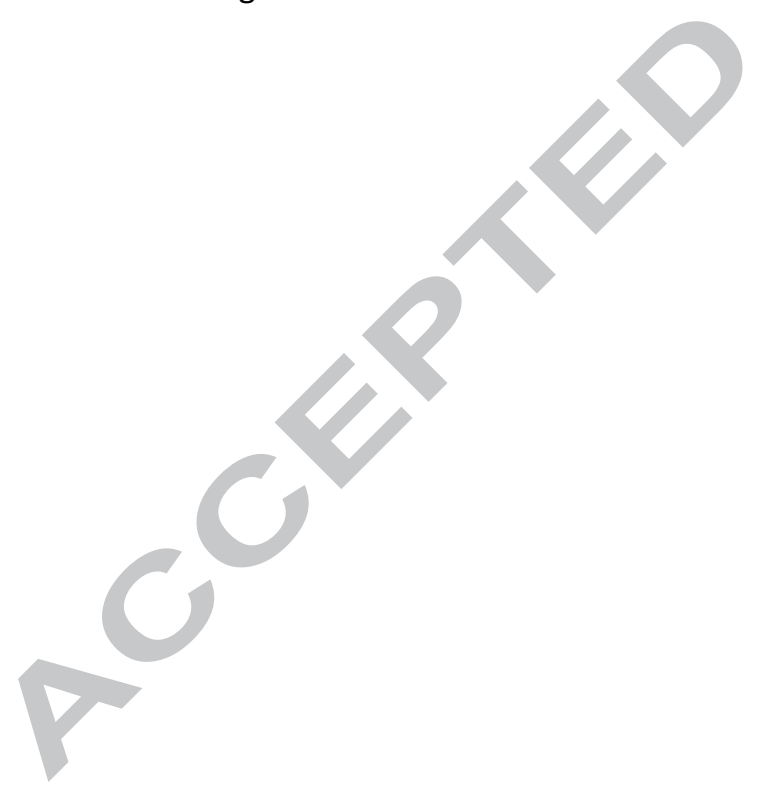




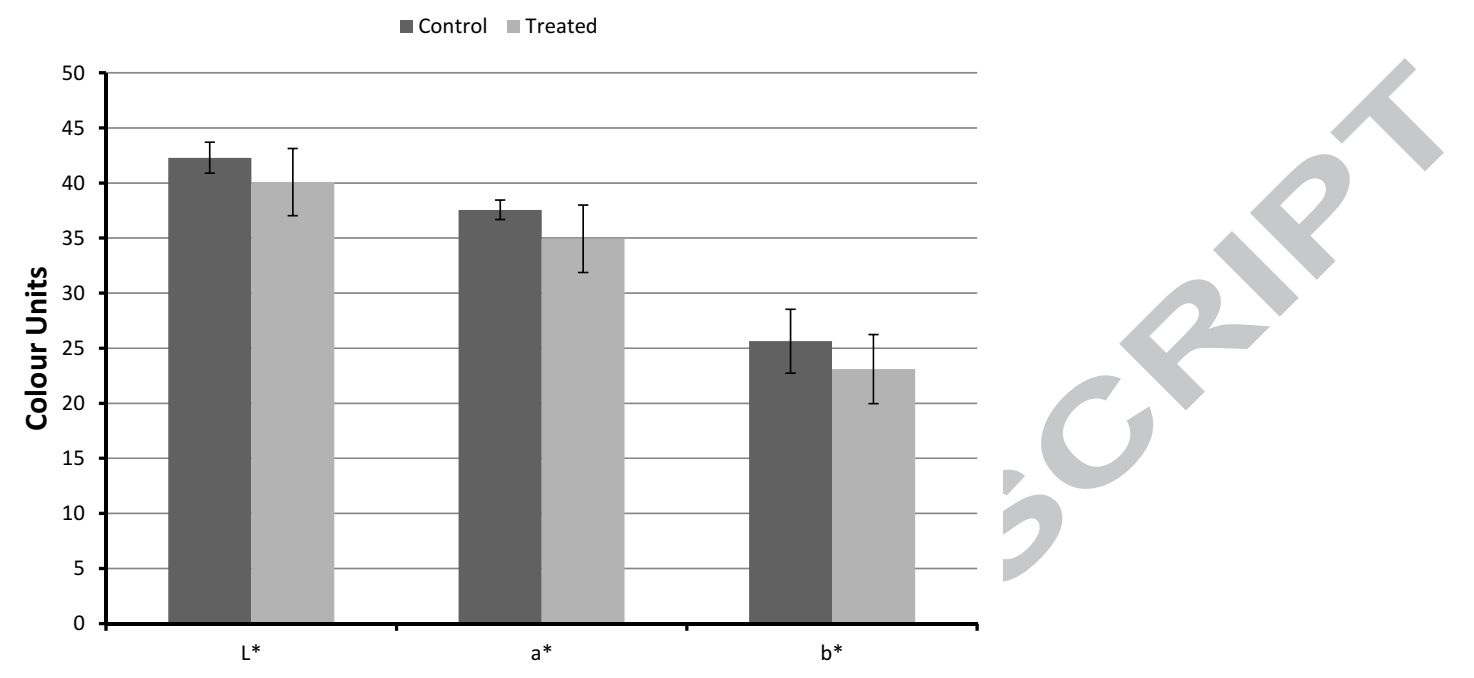

Figure 6 


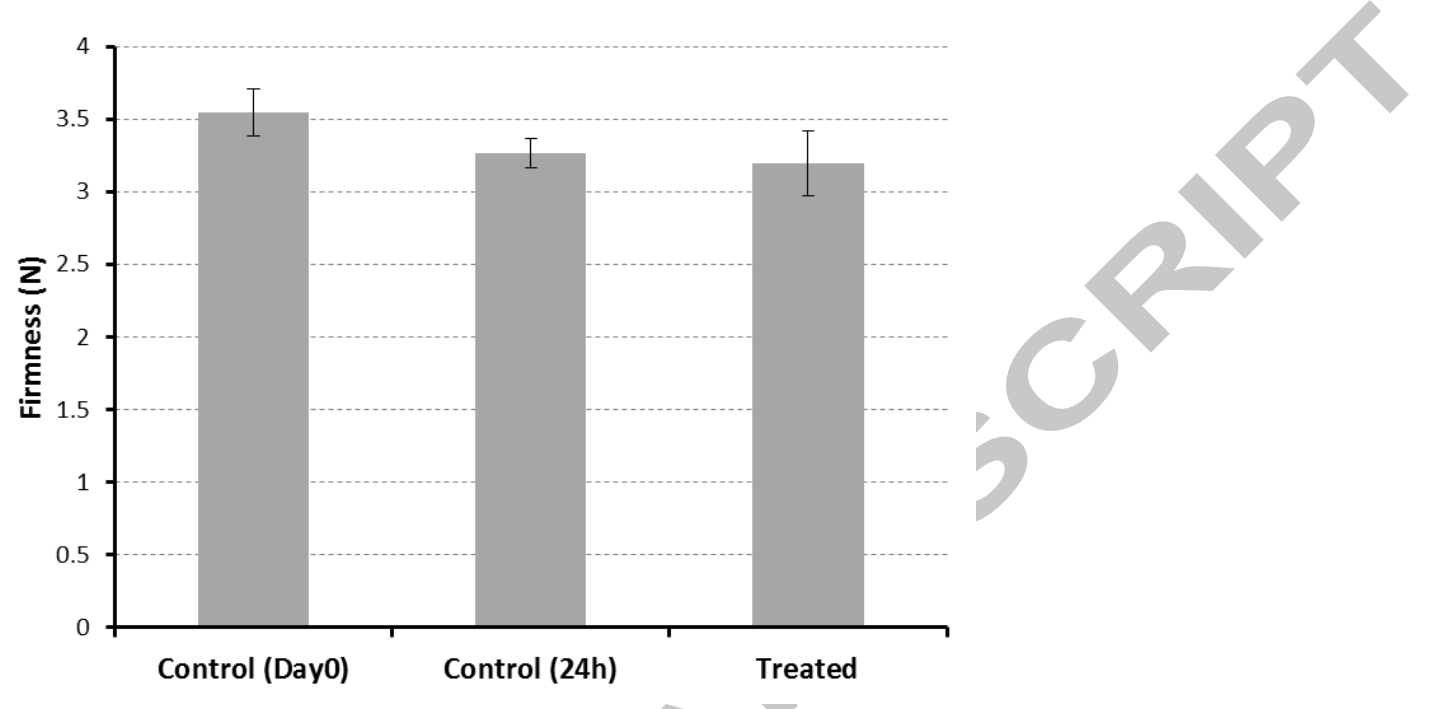

Figure 7 
Table 1 Discharge electrical parameters derived from Q-V measurements.

\begin{tabular}{ccc}
\hline Parameter & Empty box & $\begin{array}{l}\text { Box containing } \\
\text { Strawberry }\end{array}$ \\
\hline$C_{d}[\mathrm{pF}]$ & $89 \pm 6$ & 83 \\
$C_{\text {gap }}[\mathrm{pF}]$ & 1.62 & 1.58 \\
$\mathrm{P}[\mathrm{W}]$ & 17.43 & 17.03 \\
$\Delta Q[\mathrm{nC}]$ & 8098 & 7924 \\
$\Delta t[\mathrm{~ms}]$ & 3.6 & 3.7 \\
\hline
\end{tabular}


Table 2: Microbial reductions on strawberry surface by indirect atmospheric cold plasma (ACP) treatment in air

\begin{tabular}{llll}
\hline Microorganisms & $\begin{array}{l}\text { Initial population } \\
\left(\log _{10} \mathrm{cfu} / \mathrm{g}\right) \\
\text { untreated }\end{array}$ & $\begin{array}{l}\text { Untreated control } \\
\text { stored at } 10^{\circ} \mathrm{C} \text { for } \\
24 \mathrm{~h}\end{array}$ & $\begin{array}{l}\text { ACP treated surviving } \\
\text { population }\left(\log _{10} \mathrm{cfu} / \mathrm{g}\right)\end{array}$ \\
\hline Total mesophiles & $4.99 \pm 0.02$ & $4.92 \pm 0.14$ & $2.56 \pm 1.82$ \\
Yeast/moulds & $4.96 \pm 0.08$ & $5.06 \pm 0.04$ & $\begin{array}{l}(12-85 \% \text { reduction }) \\
1.56 \pm 1.29\end{array}$ \\
& & & $(44-95 \%$ reduction $)$ \\
\hline
\end{tabular}


Table 3 Regression coefficients $K_{1}$ and $K_{2}$ (s) of equations (1) and (2) for $\mathrm{O}_{2}$ consumption and $\mathrm{CO}_{2}$ evolution, respectively.

\begin{tabular}{|c|c|c|c|c|c|}
\hline \multirow[t]{2}{*}{ Package } & \multirow{2}{*}{$\begin{array}{l}\text { Principle } \\
\text { undertaking the } \\
\text { respiration rate }\end{array}$} & \multicolumn{2}{|c|}{$\begin{array}{l}\text { Regression } \\
\text { coefficients }\end{array}$} & \multirow[t]{2}{*}{$\begin{array}{l}\text { Coefficient of } \\
\text { determination }\end{array}$} & \multirow[t]{2}{*}{ RMSE } \\
\hline & & $K_{1}$ & $K_{2}$ & & \\
\hline \multirow[t]{2}{*}{ Control } & $\mathrm{CO}_{2}$ evolution & 4.0787 & 300.67 & 0.99 & 0.00182 \\
\hline & $\mathrm{O}_{2}$ consumption & 4.4978 & 306.96 & 0.99 & 0.00203 \\
\hline \multirow{2}{*}{$\begin{array}{l}5 \mathrm{~min} A C P \\
\text { treated }\end{array}$} & $\mathrm{CO}_{2}$ evolution & 5.0637 & 272.27 & 0.98 & 0.00488 \\
\hline & $\mathrm{O}_{2}$ consumption & 2.9615 & 476.76 & 0.99 & 0.00355 \\
\hline
\end{tabular}




\section{Highlights}

- In-package cold plasma processing treatment of strawberries based on dielectric barrier plasma discharge.

- Electrical characterisation of the plasma discharge revealed a filamentary regime and ozone production.

- A significant background microflora reduction was achieved.

- No adverse changes in respiration rates, texture and colour of treated strawberries. 